\title{
Variation of Vertebral Numbers with Fish Length in Atlantic Cod (Gadus morhua) of the Eastern Newfoundland Area, 1947-71
}

\author{
Wilfred Templeman \\ Department of Fisheries and Oceans, Science Branch \\ Northwest Atlantic Fisheries Centre, P. O. Box 5667 \\ St. John's, Newfoundland, Canada A1C 5X1
}

\begin{abstract}
Means of vertebral numbers in cod samples collected in 1947-71 from the eastern Newfoundland and Labrador area were compared by length-ranges.

In NAFO Div. 2GHJ and 3KL, the northern-type high-vertebral means (usually over or slightly below 55) were usually present at the length-ranges of lesser length, declining toward lower means at greater sizes. The high-vertebral-type mean extended to higher length-ranges northward than southward. In coastal areas of Div. $2 \mathrm{GHJ}$ and $3 \mathrm{~K}$, the means at the same length-ranges tended to be somewhat lower than offshore. Means at the same length-ranges for the above areas were usually a little higher in the earlier period, 1947-55, than in the later period, 1958-71. Throughout the area (not including Div. $3 \mathrm{M}$ ) offshore and inshore vertebral means at the same length-range and period were typically lower in the southern than in the adjacent northern area. The vertebral means of the relatively isolated cod stock on Flemish Cap (Div. 3M) were intermediate between the northern- and the southern-types, and on the southern Grand Bank (Div. 3NO) the means (usually below 54) were typically the lowest in the eastern Newfoundland area. Within each of these areas (Div. $3 \mathrm{M}$ and $3 \mathrm{NO}$ ), means did not differ greatly by length-range and from the earlier to the later period.
\end{abstract}

It appears that stock mixing is the primary mechanism causing the observed, relatively large, variations in mean vertebral number of the larger compared with those of the smaller fish. The lack of seasonal variation in mean vertebral numbers in offshore northern areas indicates that straying of larger fish from more southern or inshore stocks accounts for decreasing vertebral number with size. However, larval drift and mixing from seasonal migration are important causative factors of differences found in other areas. Differential fishing pressure on stocks could be the cause of temporal trends in vertebral counts in mixing areas.

\section{Introduction}

The differences in biology of cod in various parts of the eastern Labrador and Newfoundland area make a study of vertebral numbers with fish size useful. Templeman (1981) noted that the high vertebral numbers characteristic of the Labrador-East Newfoundland stock complex predominate in the smaller cod coastally southward to the St. John's area. Lear and Wells (1984) reported that the vertebral averages of juvenile cod collected during 1956-70 in the coastal areas of Labrador and eastern Newfoundland, showed that the $0+, 1$-year-old and 2-year-old cod were mainly of the high-vertebral-count northern-type typical of the NAFO Div. $2 \mathrm{GHJ}$ and $3 \mathrm{~K}$. The high-vertebral-count $0+$ and 1-year-old cod extended southward to the southeastern part of the Avalon Peninsula. Fleming (1960) and May et al. (1956) found considerable differences in population parameters of cod in the Newfoundland area from Labrador to the southern Grand Bank, the slowest growth rate, the smallest sizes and ages at sexual maturity and the smallest maximal sizes of cod being off Labrador.

This paper shows differences in vertebral means at various length-ranges of cod in NAFO Divisions (Fig. 1) of the eastern Newfoundland area (Div. 2GHJ and $3 \mathrm{KL}$ ) and relates the differences to the biology of the cod.

\section{Materials and Methods}

Vertebral counts for samples of mainly $70-120 \mathrm{~cm}$ cod from research and commercial fishing vessel catches in 1947-71 were combined usually by $20 \mathrm{~cm}$ fish-length-ranges, separately as either inshore or offshore for two periods 1947-55 and 1958-71 for NAFO Divisions of the eastern Newfoundland area. Sample 


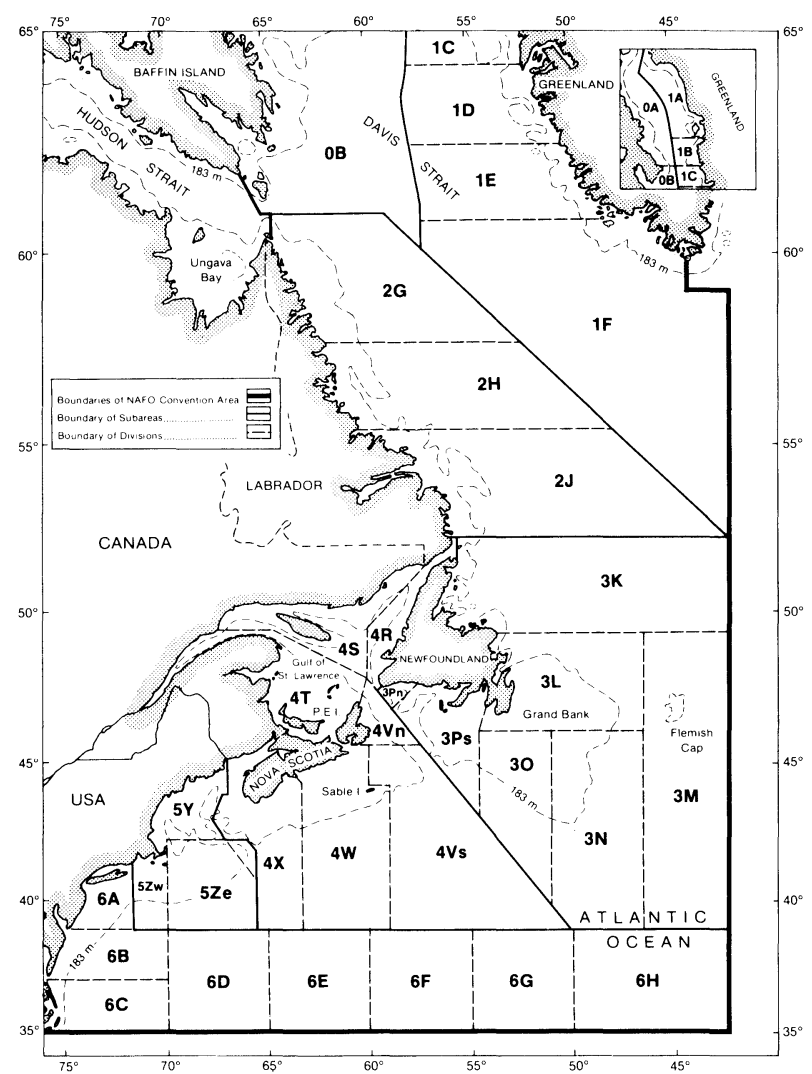

Fig. 1. Map of the NAFO Convention Area

locations and numbers, methods of collection and preparation of vertebral columns and of counting vertebrae are described in Templeman (1981). The urostylar half-vertebra was included as a vertebra and vertebral columns with fused vertebrae were not included in the averages. Fish lengths were total lengths from snout to midfork of the caudal fin. Statements regarding significance refer to the $P \leqslant 0.05$ level. Statistical information was calculated to three decimal places and rounded to two for the tables. When numbers for each sample were 30 or more and the variances were not significantly different, the usual $t$ test was used. When one or both of the samples had numbers less than 30 , the samples were calculated for independence at their $95 \%$ confidence limits. When numbers were 30 or more and variances were unequal, the $t^{\prime}$ test of Snedecor and Cochran (1980) was used.

The Labrador (Div. 2GHJ) inshore samples were taken by trap or jigger at depths usually less than $35 \mathrm{~m}$ but occasionally in 45-50 m, and generally within 1 or 2 naut. miles from the coast. The offshore samples were from depths usually greater than $180 \mathrm{~m}$ and ranging from 160 to $450 \mathrm{~m}$. The inshore samples from the Northeast Newfoundland Shelf (Div. 3K) were taken in about 20-130 m depth near the coast, mainly in the shallower water by cod trap or longline, and the deeper samples were taken on coastal shelves by longline or gillnet.
The offshore samples from Div. $3 \mathrm{~K}$ were from 180 to 320 $m$ depths. In Div. 3L, inshore (coastal, coastal shelf and bay) samples from north of St. John's $\left(3 L_{1}\right)$ included all samples north of Cape St. Francis $\left(47^{\circ} 49^{\prime} \mathrm{N}\right)$ and west of $52^{\circ} \mathrm{W}$. Samples from the St. John's area $\left(3 \mathrm{~L}_{2}\right)$ were taken near the coast and on the coastal shelf between $47^{\circ} \mathrm{N}$ and Cape St. Francis and west of $52^{\circ} 30^{\prime} \mathrm{W}$. Inshore samples from south of St. John's $\left(3 \mathrm{~L}_{3}\right)$ included the coast and coastal shelf out to about $90 \mathrm{~m}$ depth and the coastal bay samples of the southern part of the Avalon Peninsula south of $47^{\circ} \mathrm{N}$. Division $3 \mathrm{~L}$ offshore $\left(3 \mathrm{~L}_{4}\right)$ included all samples (Grand Bank and Avalon Channel) not included in the coastal areas of Div. $3 \mathrm{~L}$ described above. For locations of samples and number of vertebral columns per sample, see Templeman (1981).

\section{Results}

The Labrador-East Newfoundland high-vertebralcount stock complex forms the main biomass of cod from Ungava Bay and Div. $2 \mathrm{G}$ to $3 \mathrm{~K}$ and at the smaller sizes in Div. 3L, but there is a tendency for fish greater than $70 \mathrm{~cm}$ to have lower counts. Gradually from north to south in Div. 3L (inshore), stocks of the Avalon stock complex, with lower vertebral means, provide important contributions especially at the larger sizes. The high-vertebral-count cod usually extended to higher length-ranges northward than southward in these Divisions (Table 1). In Div. $3 M$ there were no obvious trends with length, whereas in Div. 3NO, mean vertebral count increased with increasing length, reached a maximum at an intermediate length group and then declined.

Off Labrador and over the Northeast Newfoundland Shelf (Div. 2GHJ and $3 \mathrm{~K}$ ), offshore vertebral means for the same area and length-range in approximately the same periods (Table 1 and Appendix) were higher in 18 of 20 pairs of offshore and inshore means (13 significantly), and higher inshore but nonsignificantly in 2 pairs.

Differences in vertebral means for the same area and length-range for early and late periods are as follows (numbers of significant differences in parentheses):

\begin{tabular}{lccccc}
\hline & \multicolumn{3}{c}{ Vertebral means } \\
\cline { 2 - 3 } & \multicolumn{2}{c}{$1958-71$} & & $1947-55$ & \\
\cline { 2 - 3 } Area & Lower & Equal & & Lower & Total \\
\hline Div. 2GHJ+3K & $17(9)$ & 0 & 1 & 18 \\
Div. 3L L $_{1}-L_{3}$ (inshore) & $9(5)$ & 2 & $2(2)$ & 13 \\
Div. 3L 4 (offshore) & $4(2)$ & 0 & $1(1)$ & 5 \\
Div. 3M & $3(1)$ & 1 & 0 & 4 \\
Div. 3NO & 2 & 0 & $3(2)$ & 5 \\
\hline
\end{tabular}


TABLE 1. Vertebral means at length ranges of cod from earlier and later periods of 1947-71. (Statistical data in Appendix. NAFO Div. $2 \mathrm{GH}$, off northern Labrador; $2 \mathrm{~J}$, off southern Labrador; $3 \mathrm{~K}$, Northeast Newfoundland Shelf; $3 \mathrm{~L}_{1}$, coastal Div. $3 \mathrm{~L}$, north of St. John's; $3 \mathrm{~L}_{2}$, coastal Div. 3L, St. John's area; $3 \mathrm{~L}_{3}$, coastal $3 \mathrm{~L}$, south of St. John's; 3L4, offshore Div. 3L, northern Grand Bank; 3M, Flemish Cap; 3NO, southern Grand Bank).

\begin{tabular}{|c|c|c|c|c|c|c|c|c|c|}
\hline \multirow{2}{*}{$\begin{array}{l}\text { Fish } \\
\text { length } \\
(\mathrm{cm})\end{array}$} & \multicolumn{9}{|c|}{ Area } \\
\hline & $2 \mathrm{GH}$ & $2 \mathrm{~J}$ & $3 K$ & $3 \mathrm{~L}_{1}$ & $3 \mathrm{~L}_{2}$ & $3 \mathrm{~L}_{3}$ & $3 \mathrm{~L}_{4}$ & $3 \mathrm{M}$ & $3 \mathrm{NO}$ \\
\hline \multicolumn{10}{|c|}{ Early period - Inshore } \\
\hline & $\begin{array}{l}1948-50 \\
\text { Jul-Aug }\end{array}$ & $\begin{array}{c}1948 \\
\text { Jul }\end{array}$ & $\begin{array}{c}1947-54 \\
\text { Jun-Aug }\end{array}$ & $\begin{array}{l}1949-54 \\
\text { Jun-Nov }\end{array}$ & $\begin{array}{l}1947-51 \\
\text { Jun-Nov }\end{array}$ & $\begin{array}{l}1949-54 \\
\text { Sep-Nov }\end{array}$ & & & \\
\hline $11-30$ & - & - & - & - & - & 55.25 & & & \\
\hline $31-50$ & 55.22 & 55.13 & 55.04 & 55.12 & 55.11 & 54.44 & & & \\
\hline $51-70$ & 55.30 & 55.23 & 55.32 & 55.25 & 55.00 & 54.26 & & & \\
\hline $71-90$ & - & 55.17 & 55.16 & 54.92 & 54.51 & 54.13 & & & \\
\hline$>90$ & - & - & - & 54.33 & 54.15 & 54.50 & & & \\
\hline
\end{tabular}

\begin{tabular}{|c|c|c|c|c|c|c|c|c|c|}
\hline \multicolumn{10}{|c|}{ Early period - Offshore } \\
\hline & $\begin{array}{l}1950 \\
\text { Aug }\end{array}$ & $\begin{array}{l}1950-54 \\
\text { Jul-Sep }\end{array}$ & $\begin{array}{l}1950-55 \\
\text { Jun-Sep }\end{array}$ & & & & $\begin{array}{l}1948-55 \\
\text { Apr-Oct }\end{array}$ & $\begin{array}{l}1949-51 \\
\text { Jul-Aug }\end{array}$ & $\begin{array}{l}1947-55 \\
\text { Jan-Oct }\end{array}$ \\
\hline $11-30$ & - & - & - & & & & 55.59 & 54.87 & 53.56 \\
\hline $31-50$ & 55.65 & 55.38 & 55.39 & & & & 54.63 & 54.70 & 53.76 \\
\hline $51-70$ & 55.56 & 55.51 & 55.45 & & & & 54.83 & 54.59 & 53.80 \\
\hline $71-90$ & - & 55.44 & 55.12 & & & & 54.59 & $54.66^{\mathrm{a}}$ & 54.05 \\
\hline$>90$ & - & 54.63 & 54.86 & & & & 54.29 & - & 53.65 \\
\hline \multicolumn{10}{|c|}{ Late period - Inshore } \\
\hline & $1959-64$ & $1959-64$ & $1962-65$ & $1962-70$ & $1963-71$ & $1963-69$ & & & \\
\hline & Jul-Aug & Jul-Sep & Jun-Nov & Feb-Nov & Feb-Dec & May-Nov & & & \\
\hline $11-30$ & - & 55.27 & - & 55.29 & $55.19^{b}$ & 55.25 & & & \\
\hline $31-50$ & 55.12 & 54.84 & 54.58 & 55.02 & 54.83 & 54.76 & & & \\
\hline $51-70$ & 55.25 & 54.98 & 54.77 & 54.74 & 54.61 & 54.54 & & & \\
\hline $71-90$ & 54.79 & 54.44 & 54.54 & 54.41 & 54.25 & 54.00 & & & \\
\hline$>90$ & - & 54.08 & 53.70 & 54.03 & 54.15 & 54.24 & & & \\
\hline \multicolumn{10}{|c|}{ Late period - Offshore } \\
\hline & $1959-60$ & $1958-66$ & $1962-64$ & & & & $1961-70$ & $1961-64$ & 1964-69 \\
\hline & Jul-Sep & Mar-Sep & Apr-Sep & & & & Jan-Oct & Mar-Jul & Apr-Nov \\
\hline $11-30$ & 55.49 & 55.29 & 55.12 & & & & 55.18 & 54.40 & 53.87 \\
\hline $31-50$ & 55.41 & 55.31 & 55.33 & & & & 54.89 & 54.68 & 53.98 \\
\hline $51-70$ & 55.38 & 55.36 & 55.27 & & & & 54.45 & 54.59 & 54.13 \\
\hline $71-90$ & 55.22 & 54.84 & 54.32 & & & & 54.08 & $54.65^{\mathrm{a}}$ & 53.98 \\
\hline$>90$ & - & 55.33 & 54.46 & & & & 54.11 & - & 53.55 \\
\hline
\end{tabular}

${ }^{\mathrm{a}} 71->90 \mathrm{~cm} ;{ }^{\mathrm{b}} 31-40 \mathrm{~cm}$

Thus, for the northern Div. 2GHJ and 3K, comparable vertebral means were lower in the later than in the earlier period. Means of the isolated Flemish Cap stock (Div. 3M) were also lower in the later period. In Div. 3L, means were usually lower in the later than in the earlier period, but not as distinctly so as for the more northern Divisions. In Div. 3NO, in contrast, means of the later period tended to be higher than those of the earlier.

Comparable vertebral means declined from north to south. Comparing means from northern areas (Table 1 and Appendix) for the same length-ranges (for inshore and offshore, early and later periods separately) with those of the more southern adjacent area gave the results below (numbers significantly different in parentheses):

\begin{tabular}{lccc}
\hline & \multicolumn{2}{c}{$\begin{array}{c}\text { Adjacent southern } \\
\text { area mean }\end{array}$} & \\
\cline { 2 - 3 } Area & Lower & Higher & Total \\
\hline Div. 2GHJ+3K & $22(10)$ & 5 & 27 \\
Div. 3K, 3L $-L_{3}$ (inshore) & $17(9)$ & $6(1)$ & 23 \\
Div. 3K, 3L, $3 N$ (offshore) & $18(13)$ & 1 & 19 \\
Total & $57(32)$ & $12(1)$ & 69 \\
\hline
\end{tabular}

\section{Discussion}

Judging by vertebral means and high and low vertebral numbers (Templeman, 1981) the purest part of the Labrador-East Newfoundland stock complex is in Ungava Bay and off northern Labrador where the cod 
are most removed from intermingling with other stocks. The offshore populations of Div. $2 \mathrm{GH}$ to $3 \mathrm{~K}$ are also more typical of the northern stock than the inshore populations, possessing high vertebral numbers except at the greatest length-ranges. Progressively from Div. 2J southward, the largest cod have lower vertebral numbers more typical of southern or Gulf of St. Lawrence stocks or of cod from the coastal areas. The decline in vertebral means from Div. $2 \mathrm{GH}$ to $3 \mathrm{~L}$ indicates that progressively southward there are increasing numbers of low-vertebral-count cod which are evident especially at the greatest lengths.

Possible sources of the low-vertebral-count cod present at the larger sizes toward the north are the occasional migrants from the northern part of the Gulf of St. Lawrence and from the lower-vertebral-count northern coastal cod and Avalon and southern Grand Bank stocks (Templeman and Fleming, 1962; Templeman, 1974, 1979, 1981). The migrants from these areas are likely to be mainly mature fish. The smaller immature cod of the northern Gulf or Grand Bank and related stocks are unlikely to move in numbers to the northern areas. It is evident from Fleming (1960, figure 5) that southern Grand Bank cod mature at larger sizes and attain much greater maximum size than the Labrador cod. The fastest-growing cod, those from the southern Grand Bank, were on the average 30\% longer at age 5 and $75 \%$ longer at age 15 than those from the area of slowest growth, northern Labrador (Templeman, 1965). In the northern Divisions, the numbers of cod at these greater lengths were few compared with those at the smaller lengths and with those at greater lengths in southern areas. Some smaller cod of low vertebral numbers presumably also wander into northern highvertebral-count areas, but, as deduced from vertebral means, are not so evident as at the higher lengthranges where the numbers of the slow-growing highvertebral-count stocks are relatively fewer. It was possible to test whether the movement of large, lowvertebral-count fish into offshore northern areas was of a seasonal nature. In 1958-66 the offshore samples from Div. 2J (Table 1 and Appendix) included 18 samples $(2,288$ cod) from 31 March to 11 June, the spring spawning period, and 7 samples $(764 \mathrm{cod})$ in AugustSeptember, the late summer-early autumn feeding season. Vertebral numbers of these two seasonal groups were as follows:

\begin{tabular}{cccr}
\hline $\begin{array}{c}\text { Length range } \\
\text { of fish } \\
(\mathrm{cm})\end{array}$ & $\begin{array}{c}\text { Mean } \\
\text { vertebral } \\
\text { number }\end{array}$ & $\begin{array}{c}\text { Standard } \\
\text { error }\end{array}$ & $\begin{array}{c}\text { No. of } \\
\text { fish }\end{array}$ \\
\hline \multicolumn{4}{c}{ March to early June } \\
$11-30$ & 55.31 & 0.06 & \\
$31-50$ & 55.28 & 0.02 & 155 \\
$51-70$ & 55.37 & 0.03 & 1,318 \\
$71-110$ & 55.00 & 0.17 & 767 \\
& & & 48
\end{tabular}

\begin{tabular}{cccr} 
(continued). & & \\
\hline $\begin{array}{c}\text { Length range } \\
\text { of fish } \\
(\mathrm{cm})\end{array}$ & $\begin{array}{c}\text { Mean } \\
\text { vertebral } \\
\text { number }\end{array}$ & $\begin{array}{c}\text { Standard } \\
\text { error }\end{array}$ & $\begin{array}{c}\text { No. of } \\
\text { fish }\end{array}$ \\
\hline \multicolumn{4}{c}{ August-September } \\
$11-30$ & 55.23 & 0.11 & 40 \\
$31-50$ & 55.44 & 0.05 & 210 \\
$51-70$ & 55.35 & 0.04 & 483 \\
$71-110$ & 54.74 & 0.18 & 31 \\
\hline
\end{tabular}

The pattern of high vertebral counts in $11-70 \mathrm{~cm}$ fish and lower vertebral counts in $71-110 \mathrm{~cm}$ fish is similar in both sets of monthly periods. The vertebral means at the largest sizes were lower in the later than in the earlier months but the differences at the same lengthranges are not significant. The offshore Div. 3K group in the later period (1962-64), can also be separated into spring (April-May) and early autumn (September) samples (14 samples, 1,909 fish, and 2 samples, 214 fish respectively) with results as follows:

\begin{tabular}{cccr}
\hline $\begin{array}{c}\text { Length range } \\
\text { of fish } \\
(\mathrm{cm})\end{array}$ & $\begin{array}{c}\text { Mean } \\
\text { vertebral } \\
\text { number }\end{array}$ & $\begin{array}{c}\text { Standard } \\
\text { error }\end{array}$ & $\begin{array}{r}\text { No. of } \\
\text { fish }\end{array}$ \\
\hline \multicolumn{4}{c}{ April-May 1962-64 } \\
$11-30$ & 55.10 & 0.05 & 199 \\
$31-50$ & 55.34 & 0.03 & 1,034 \\
$51-70$ & 55.32 & 0.04 & 613 \\
$71-120$ & 54.33 & 0.15 & 63 \\
& & & 30 \\
$11-30$ & September 1962-63 & 67 \\
$31-50$ & 55.30 & 0.18 & 91 \\
$51-70$ & 55.13 & 0.09 & 26 \\
$71-120$ & 54.90 & 0.11 & \\
\hline
\end{tabular}

In both April-May and in September, the $11-50 \mathrm{~cm}$ fish had northern type higher vertebral means in comparison with the lower means of the 71-120 cm fish. The vertebral means of the $51-70 \mathrm{~cm}$ fish were also somewhat low in September but not in April-May. Thus, in both cases examined, season was not an important factor in explaining mean vertebral count variation.

The similar picture of declining vertebral means from small to large fish in northern areas in different periods, $10-15$ years apart, gave no indication that the great decreases in vertebral means with increasing fish length were due to year-class differences in the same stocks. Ten to fifteen years would provide enough time for the high-vertebral-count fish of the earlier periods shown in Table 1 to grow to lengths which actually had low-vertebral-count fish in the later periods.

The Labrador-East Newfoundland stock complex is known to spawn in Div. $2 \mathrm{GHJ}$ and $3 \mathrm{~K}$ and spawning of this stock is doubtful in Div. 3L (Templeman, 1979). 
For Div. 3L, there was a general picture of the smaller fish, i.e. those from settling of fry of the Labrador-East Newfoundland stock complex and their consequent growing up as immatures in the area, possessing the high vertebral numbers characteristic of this northern stock complex. At intermediate sizes there was intermingling with low-vertebral-count cod of the local Avalon stock complex and of the southern Grand Bank to produce lower vertebral numbers. At the greatest lengths, the population was almost entirely of the southern type, with low vertebral numbers, because the northern cod usually do not grow to the greater lengths typical of the southern fish.

Migration studies showed some movement of cod from the southern Grand Bank (Div. 3NO), St. Pierre Bank and vicinity, to Div. $3 \mathrm{~L}$ and vice versa, and return of cod from the spawning areas of the Labrador-East Newfoundland stock complex to their feeding areas in Div. 3L (Thompson, 1943; Templeman and Fleming, 1962; Templeman, 1974, 1979; Lear, 1984).

Southern Grand Bank (Div. 3NO) is occupied mainly by the low-vertebral-count southern Grand Bank stock but with some intrusions from the northward of high-vertebral-count stock (Templeman, 1962, 1974, 1979, 1981; Postolaky, 1962). It is evident that, because of the greater length at sexual maturity and the high growth rate of the southern Grand Bank lowvertebral-count stock and the smaller length at sexual maturity and low growth rate of the high-vertebralcount northern stock complex, these largest fish with the lowest vertebral means were most likely to be southern Grand Bank stock. Similarly the smallest immatures which had the next lowest vertebral means and presumably migrate little compared with larger fish were apparently mostly southern Grand Bank stock. The higher vertebral means of the cod of intermediate length were mainly due to the intrusion of highervertebral-count fish of the northern and Avalon stocks to mix with the southern Grand Bank stock. The extent of these migrations is indicated in Templeman (1974, 1979) and also by the vertebral means of Templeman (1981) and of Postolaky (1962). Much or most of the intrusion is around the northeastern slope of the Grand Bank into the northeastern portion of Div. 3N and from the coast and from northwestern Grand Bank into the northwestern part of Div. 30. The intermediate lengthranges were most affected by the movements from the north and northwest, and the largest were affected very little because the larger immature and the mature slower-growing cod from the north and northwest were mainly of intermediate sizes which, because of their earlier maturity and slower growth, did not usually reach the greater lengths characteristic of the southern Grand Bank stock.

The Flemish Cap cod stock, as reviewed by Templeman (1976) and Lear et al. (1981), was shown by many authors and by many biological differences to be relatively isolated from other cod stocks of the Newfoundland area. The small differences in vertebral means between length-ranges and between periods on Flemish Cap, together with the large degree of isolation of the stock by the deep Flemish Channel, indicate that the small differences in vertebral means on the Cap were due to random differences or to differences between year-classes (Lear et al., 1981).

The trend towards lower vertebral counts in more southern areas is in conformity with the commonly made observation that fish which develop in warmer waters have lower meristic counts. The observation that inshore cod had lower vertebral counts than offshore cod of the same length in Div. $2 \mathrm{GHJ}, 3 \mathrm{~K}$ may be partly related to later spawning in inshore areas, which could also place some inshore eggs and larvae in relatively warmer waters.

There is evidence (Templeman, 1964, and below) that in Div. $2 \mathrm{~J}$ and $3 \mathrm{~K}$, cod spawning closer to the coast have higher percentages of late spawners than those subjected to the main fisheries farther offshore on the continental slopes. Spawning later in the year should produce cod with lower vertebral numbers if upper layer water temperatures are higher. In 9-16 April 1963, in the Hamilton Bank region of Div. $2 \mathrm{~J}$, research vessel samples of 71 mature females from the southeastern and eastern slopes of Hamilton Bank (2J) contained $71 \%$ spent fish, $8 \%$ partly spent and the remainder were ripening to spawn in that year. At the same time in the same general area but in the western part of Hawke Channel, closer to the coast, cod were spawning later. In samples of 28 mature females, the percentages were $28 \%$ spent, $8 \%$ partly spent and $64 \%$ ripening. In early May 1963 in Div. 3K, there was a greater proportion of female cod in research vessel catches spawning later in the deep water of the coastal shelf than on Funk Island Bank where bottom temperatures were higher. In coastal areas $81 \%$ of 155 mature females were spent whereas $91 \%$ of 87 mature females on Funk Island Bank were spent. Bottom water temperatures were $-0.9^{\circ}$ to $2.9^{\circ} \mathrm{C}$ and $2.4^{\circ}$ to $3.3^{\circ} \mathrm{C}$ respectively. In both Div. $2 \mathrm{~J}$ and $3 \mathrm{~K}$, the later spawning was especially evident in the older year-classes and largest sizes.

The observations of Chrzan (1968) for 1967 are indefinite regarding location, but appear to indicate that in the colder water closer to the coast there is later spawning. He says that "from our observations on the maturity of the gonads, it appears that, in Div. $2 \mathrm{~J}$ cod, spawning in the deeper waters was into its final stage in May, whereas in the shallower waters it was considerably retarded". This, along with Canadian research vessel data for 1963, indicates that some delayed spawning occurs in coastal waters, possibly as a result of lower bottom-water temperatures. This could have the result of placing some eggs and larvae in warmer surface 
waters than what prevails during earlier spawning on the offshore banks.

The strong tendency for vertebral counts to be lower in the 1958-71 period than earlier in the inshore northern areas could be partly a result of increased winter-spring catches of the northern stock complex. The offshore catch was twice the inshore catch in Subarea 2 (predominantly in Div. 2J) in 1951-53 (ICNAF, 1952-57). In 1959 the offshore catch from Div. 2J was still twice the inshore catch, whereas in 1960-66 it ranged from 8 to 14 times the inshore catch (Lear et al., 1986). The offshore cod catch in Div. 3K from 1953 to 1955 was 0.3 times the inshore catch (ICNAF, 1952-57) and the yearly offshore catch in 1960-65 averaged 1.7 times the inshore catch (Lear et al., 1986). Most of these offshore catches were taken in winter-spring before the cod migrated inshore from the wintering and spawning areas. In $1969,71 \%$ of the catch of 412,000 tons of cod off Labrador (Subarea 2) was taken in January-March and $92 \%$ before the end of June (Templeman, 1972). The increased fishing in winter-spring on the offshore high-vertebral-count populations in Div. $2 \mathrm{~J}$ and $3 \mathrm{~K}$ left much smaller numbers of these fish to intermingle in summer-autumn with the inshore populations which evidently had more fish with lower vertebral numbers. This would tend to lower the vertebral means of coastal cod in Div. $2 \mathrm{~J}$ and $3 \mathrm{KL}$ in the summer-autumn in the later more than in the earlier period (Table 1).

\section{Conclusions}

1. In Div. $2 \mathrm{GHJ}$ and $3 \mathrm{KL}$, vertebral means of the smaller cod were of the high-vertebral-count northern-type, declining toward the low-vertebralcount southern-type at greater lengths. The highvertebral-type mean extended to higher length-ranges in the north than in the south.

2. In the calculations of vertebral means for the northern part of the eastern Newfoundland area, cod of the larger sizes were relatively scarce, increasing in numbers relative to those at the smaller sizes from north to south.

3. Vertebral means of offshore cod in Div. 2GHJ and $3 \mathrm{~K}$ were typically higher than the inshore means for the same fish length-range, Division and approximately the same periods.

4. Vertebral means in the same area, time period and length-range in Div. 2GHJ and $3 \mathrm{~K}$, and usually for Div. $3 \mathrm{~L}$ and $3 \mathrm{M}$, were higher in the earlier, 1947-55, than in the later, 1958-71, period; the reverse tended to be the case in Div. 3NO.

5. Vertebral means in Div. 2GHJ and 3KLNO were typically lower in the southern than in the adjacent northern Division or combined Divisions at the same length-range, approximate period, and inshore or offshore location. This is explainable by the somewhat later spawning and hence higher upper water temperature at egg development in southern than in northern areas.

6. In Div. $2 \mathrm{~J}$ and $3 \mathrm{~K}$, samples from spring-early June and late summer-early autumn had high vertebral numbers at smaller length-ranges and low vertebral numbers at the largest length-ranges indicating that mixing was a result of straying rather than of seasonal migrations.

7. Stock mixing from drifts of larvae and fry in water currents, later straying of cod of different stocks, often with different growth rates and intermingling of stocks in feeding season account in large part for differences in vertebral numbers observed at different fish length ranges.

8. In Div. $2 \mathrm{~J}$ and $3 \mathrm{~K}$, there was some later spawning in areas closer to the coast than in the truly offshore deepwater areas. The later spawning was relatively greater in the older year-classes and largest sizes. The later spawning could produce lower vertebral numbers in inshore cod compared to offshore cod in the same Division.

9. The greatly increased winter-spring fishery in the early-1960s on the high-vertebral-count populations in offshore Div. $2 \mathrm{~J}$ and $3 \mathrm{~K}$, left much smaller numbers of these fish on their return migration to intermingle with the inshore populations, which evidently had more fish with lower vertebral numbers. This was probably a factor in lowering inshore vertebral numbers in the 1960s.

\section{References}

CHRZAN, F. 1968. Polish research report, 1967. ICNAF Redbook, 1968(II): 75-84.

FLEMING, A. M. 1960. Age, growth and sexual maturity of cod (Gadus morhua L.) in the Newfoundland area, 1947-50. J. Fish. Res. Board Can., 17: 775-809.

ICNAF. 1952-57. Fishery Statistics. ICNAF Stat. Bull., vols. 1-5 for 1951-55.

LEAR, W. H. 1984. Discrimination of the cod stock complex of Atlantic cod (Gadus morhua) off southern Labrador and eastern Newfoundland, as inferred from tagging studies. J. Northw. Atl. Fish. Sci., 5: 143-159.

LEAR, W. H., J. W. BAIRD, J. C. RICE, J. E. CARSCADDEN, G. R. LILLY, and S. A. AKENHEAD. 1986. An examination of factors affecting catch in the inshore cod fishery of Labrador and eastern Newfoundland. Can. Tech. Rep. Fish. Aquat. Sci., 1469: iv $+71 \mathrm{p}$.

LEAR, W. H., and R. WELLS. 1984. Vertebral averages of juvenile cod, Gadus morhua, from coastal waters of eastern Newfoundland and Labrador as indicators of stock origin. J. Northw. Atl. Fish. Sci., 5: 23-31.

LEAR, W. H., R. WELLS, and W. TEMPLEMAN. 1981. Variation in vertebral averages for year-classes of Atlantic cod, Gadus morhua, on Flemish Cap. J. Northw. Atl. Fish. Sci., 2: $57-60$. 
MAY, A. W. A. T. PINHORN, R. WELLS, and A. M. FLEMING. 1965. Cod growth and temperatures in the Newfoundland area. ICNAF Spec. Publ., 6: 545-555.

POSTOLAKY, R. I. 1962. Biology of the Labrador and Newfoundland cod. In: Soviet Fisheries Investigations in the Northwest Atlantic, VNIRO-PINRO, Moscow, p. 338-348 (Transl. for U.S. Dept. Int., Nat. Sci. Found., Washington, D.C. by Israel Prog. Sci. Transl., 1963).

SNEDECOR, G. W., and W. C. COCHRAN. 1980. Statistical methods (7th ed.). The lowa State Univ. Press, Ames, lowa, U.S.A., 507 p.

TEMPLEMAN, W. 1962. Divisions of cod stocks in the Northwest Atlantic. ICNAF Redbook, 1962(III): 79-129.

1964. Canadian research report, 1963. A. Subareas 2 and 3. ICNAF Redbook, 1964(II): 3-21.

1965. Canadian research report, 1964. A. Subareas 2 and 3. ICNAF Redbook, 1965(II): 3-20.

1972. Subarctic marine living resources. Trans. Roy. Soc. Can., Ser. 4, 10: 259-295.

1974. Migrations and intermingling of Atlantic cod
(Gadus morhua) stocks of the Newfoundland area. J. Fish. Res. Board Can., 31: 1073-1092.

1976. Biological and oceanographic background of Flemish Cap as an area for research on the reasons for year-class success and failure in cod and redfish. ICNAF Res. Bull., 12: 91-117.

1979. Migration and intermingling of stocks of Atlantic cod (Gadus morhua), of the Newfoundland and adjacent areas from tagging in 1962-66. ICNAF Res. Bull., 14: 5-50.

1981. Vertebral numbers in Atlantic cod, Gadus morhua, of the Newfoundland and adjacent areas, 1947-71 and their use for delineating cod stocks. J. Northw. Atl. Fish. Sci., 2: 21-45.

TEMPLEMAN, W., and A. M. FLEMING. 1962. Cod tagging in the Newfoundland area during 1947 and 1948. J. Fish. Res. Board Can., 19: 445-487.

THOMPSON, H. 1943. A biological and economic study of cod (Gadus callarias L.) in the Newfoundland area. Nfld. Dept. Nat. Resour. Fish. Bull., 14: 160 p. 


\section{Appendix}

Standard error and sample size (in parenthesis) corresponding to vertebral means of Table 1. (Data calculated to three decimal places and rounded to two.)

\begin{tabular}{|c|c|c|c|c|c|c|c|c|c|c|c|c|c|c|}
\hline \multirow{2}{*}{$\begin{array}{l}\text { Fish } \\
\text { length } \\
(\mathrm{cm})\end{array}$} & \multicolumn{14}{|c|}{ Area } \\
\hline & \multicolumn{2}{|c|}{$2 \mathrm{GH}$} & \multicolumn{2}{|c|}{$2 \mathrm{~J}$} & \multicolumn{2}{|c|}{$3 K$} & \multicolumn{2}{|c|}{$3 L_{1}$} & \multicolumn{2}{|c|}{$3 L_{2}$} & $3 L_{3}$ & $3 \mathrm{~L}_{4}$ & $3 M$ & $3 \mathrm{NO}$ \\
\hline \multicolumn{15}{|c|}{ Early period - Inshore } \\
\hline & \multicolumn{2}{|c|}{$\begin{array}{l}1948-50 \\
\text { Jul-Aug }\end{array}$} & \multicolumn{2}{|c|}{$\begin{array}{c}1948 \\
\text { Jul }\end{array}$} & \multicolumn{2}{|c|}{$\begin{array}{l}1947-54 \\
\text { Jun-Aug }\end{array}$} & \multicolumn{2}{|c|}{$\begin{array}{l}1949-54 \\
\text { Jun-Nov }\end{array}$} & \multicolumn{2}{|c|}{$\begin{array}{l}\text { 1947-51 } \\
\text { Jun-Nov }\end{array}$} & $\begin{array}{l}\text { 1949-54 } \\
\text { Sep-Nov }\end{array}$ & & & \\
\hline $11-30$ & - & & - & & - & & - & & - & & $0.14 \quad(32)$ & & & \\
\hline $31-50$ & 0.05 & (253) & 0.29 & $(16)$ & 0.12 & (96) & 0.07 & (171) & 0.06 & (338) & $0.12(107)$ & & & \\
\hline $51-70$ & 0.04 & (361) & 0.06 & (188) & 0.04 & $(596)$ & 0.04 & (607) & 0.04 & $(850)$ & $0.06(353)$ & & & \\
\hline $71-90$ & - & (4) & 0.54 & (6) & 0.13 & (43) & 0.07 & (209) & 0.07 & (274) & $0.10(127)$ & & & \\
\hline$>90$ & - & & - & & - & & 0.20 & $(27)$ & 0.12 & $(61)$ & $0.32 \quad(16)$ & & & \\
\hline
\end{tabular}

\begin{tabular}{|c|c|c|c|c|c|c|}
\hline \multirow[b]{2}{*}{$11-30$} & \multicolumn{2}{|c|}{$\begin{array}{l}1950 \\
\text { Aug }\end{array}$} & \multicolumn{2}{|c|}{$\begin{array}{c}1950-54 \\
\text { Jul-Sep }\end{array}$} & \multicolumn{2}{|c|}{$\begin{array}{l}1950-55 \\
\text { Jun-Sep }\end{array}$} \\
\hline & - & & - & & - & \\
\hline $31-50$ & 0.08 & (76) & 0.04 & (291) & 0.06 & (239) \\
\hline $51-70$ & 0.07 & (135) & 0.03 & (610) & 0.03 & (827) \\
\hline $71-90$ & - & & 0.14 & (39) & 0.07 & (175) \\
\hline$>90$ & - & & 0.26 & (8) & 0.18 & (22) \\
\hline
\end{tabular}

Early period - Offshore

\begin{tabular}{|c|c|c|c|c|c|c|c|c|c|c|}
\hline \multicolumn{11}{|c|}{ Late period - Inshore } \\
\hline \multirow[b]{2}{*}{$11-30$} & $\begin{array}{l}1959-64 \\
\text { Jul-Aug }\end{array}$ & \multicolumn{2}{|c|}{$\begin{array}{l}\text { 1959-64 } \\
\text { Jul-Sep }\end{array}$} & \multicolumn{2}{|c|}{$\begin{array}{l}1962-65 \\
\text { Jun-Nov }\end{array}$} & \multicolumn{2}{|c|}{$\begin{array}{l}1961-70 \\
\text { Feb-Nov }\end{array}$} & \multicolumn{2}{|c|}{$\begin{array}{c}1963-71 \\
\text { Feb-Dec }\end{array}$} & $\begin{array}{c}1963-69 \\
\text { May-Nov }\end{array}$ \\
\hline & - & 0.05 & (323) & - & & 0.10 & $(104)$ & 0.12 & $(51)^{b}$ & 0.45 \\
\hline $31-50$ & $0.04 \quad(532)$ & 0.04 & (523) & 0.11 & (77) & 0.05 & (482) & 0.06 & (296) & 0.09 (129) \\
\hline $51-70$ & $0.02(1,447)$ & 0.03 & $1,469)$ & 0.08 & (177) & 0.03 & $1,129)$ & 0.04 & (817) & $0.06(369)$ \\
\hline $71-90$ & $0.28 \quad(14)$ & 0.07 & (223) & 0.10 & (151) & 0.04 & (802) & 0.05 & (407) & $0.04(548)$ \\
\hline$>90$ & - & 0.21 & (13) & 0.26 & (20) & 0.07 & (204) & 0.16 & (33) & $0.06(246)$ \\
\hline
\end{tabular}

Late period - Offshore

\begin{tabular}{|c|c|c|c|c|c|c|c|c|}
\hline \multirow[b]{2}{*}{$11-30$} & \multicolumn{2}{|c|}{$\begin{array}{l}\text { 1959-60 } \\
\text { Jul-Sep }\end{array}$} & $\begin{array}{c}1958-66 \\
\text { Mar-Sep }\end{array}$ & $\begin{array}{l}1962-64 \\
\text { Apr-Sep }\end{array}$ & \multirow{2}{*}{$\begin{array}{c}\begin{array}{c}1961-70 \\
\text { Jan-Oct }\end{array} \\
0.07(167)\end{array}$} & $\begin{array}{l}1961-64 \\
\text { Mar-Jul }\end{array}$ & \multicolumn{2}{|c|}{$\begin{array}{c}1964-67 \\
\text { Apr-Nov }\end{array}$} \\
\hline & 0.07 & $(164)$ & $0.03 \quad(195)$ & $0.05 \quad$ (229) & & $0.08 \quad(96)$ & 0.05 & (521) \\
\hline $31-50$ & 0.04 & $(546)$ & $0.02(1,528)$ & $0.03(1,101)$ & $0.04(871)$ & $0.04(274)$ & 0.05 & (516) \\
\hline $51-70$ & 0.04 & (412) & $0.03(1,250)$ & $0.04 \quad(704)$ & $0.04(754)$ & $0.06(184)$ & 0.06 & (304) \\
\hline $71-90$ & 0.22 & (9) & 0.13 & 0.13 & 0.07 (223) & $0.10(49)^{a}$ & 0.07 & (223) \\
\hline$>90$ & - & (1) & 0.33 & 0.45 & 0.09 (105) & - & 0.07 & (145) \\
\hline
\end{tabular}

${ }^{\mathrm{a}} 71->90 \mathrm{~cm} ;{ }^{\mathrm{b}} 31-40 \mathrm{~cm}$. 


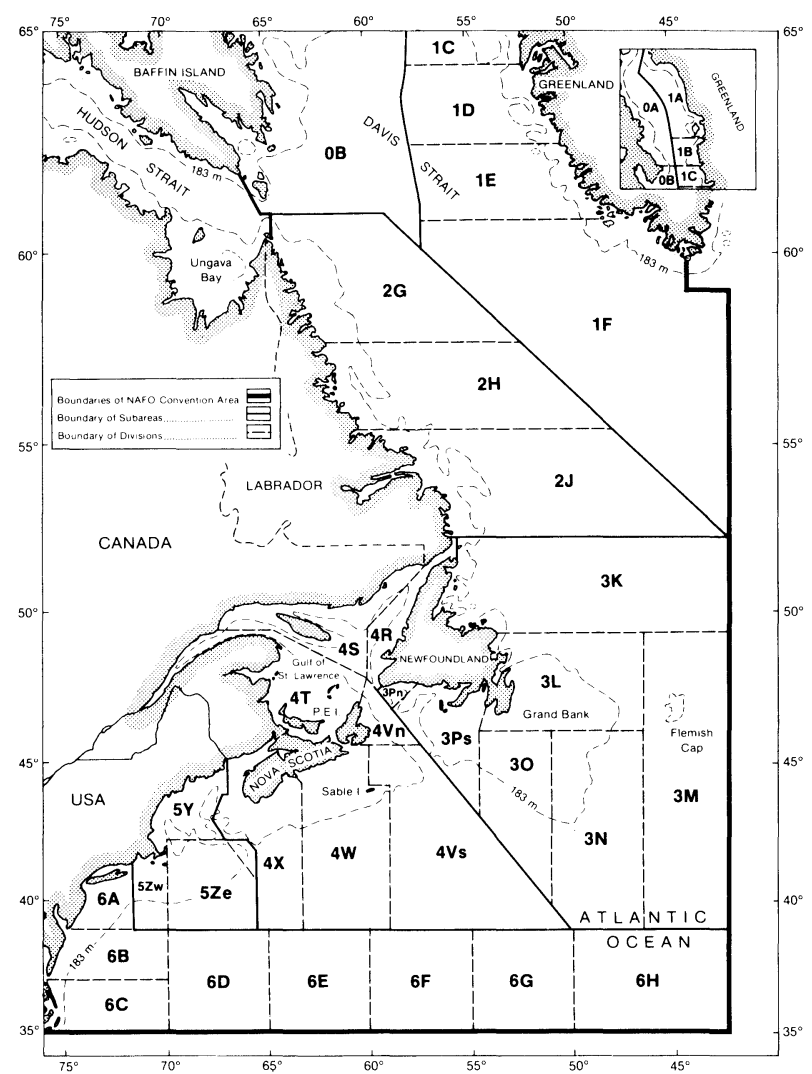

Fig. 1. Map of the NAFO Convention Area

locations and numbers, methods of collection and preparation of vertebral columns and of counting vertebrae are described in Templeman (1981). The urostylar half-vertebra was included as a vertebra and vertebral columns with fused vertebrae were not included in the averages. Fish lengths were total lengths from snout to midfork of the caudal fin. Statements regarding significance refer to the $P \leqslant 0.05$ level. Statistical information was calculated to three decimal places and rounded to two for the tables. When numbers for each sample were 30 or more and the variances were not significantly different, the usual $t$ test was used. When one or both of the samples had numbers less than 30 , the samples were calculated for independence at their $95 \%$ confidence limits. When numbers were 30 or more and variances were unequal, the $t^{\prime}$ test of Snedecor and Cochran (1980) was used.

The Labrador (Div. 2GHJ) inshore samples were taken by trap or jigger at depths usually less than $35 \mathrm{~m}$ but occasionally in 45-50 m, and generally within 1 or 2 naut. miles from the coast. The offshore samples were from depths usually greater than $180 \mathrm{~m}$ and ranging from 160 to $450 \mathrm{~m}$. The inshore samples from the Northeast Newfoundland Shelf (Div. 3K) were taken in about 20-130 m depth near the coast, mainly in the shallower water by cod trap or longline, and the deeper samples were taken on coastal shelves by longline or gillnet.
The offshore samples from Div. $3 \mathrm{~K}$ were from 180 to 320 $m$ depths. In Div. 3L, inshore (coastal, coastal shelf and bay) samples from north of St. John's $\left(3 L_{1}\right)$ included all samples north of Cape St. Francis $\left(47^{\circ} 49^{\prime} \mathrm{N}\right)$ and west of $52^{\circ} \mathrm{W}$. Samples from the St. John's area $\left(3 \mathrm{~L}_{2}\right)$ were taken near the coast and on the coastal shelf between $47^{\circ} \mathrm{N}$ and Cape St. Francis and west of $52^{\circ} 30^{\prime} \mathrm{W}$. Inshore samples from south of St. John's $\left(3 \mathrm{~L}_{3}\right)$ included the coast and coastal shelf out to about $90 \mathrm{~m}$ depth and the coastal bay samples of the southern part of the Avalon Peninsula south of $47^{\circ} \mathrm{N}$. Division $3 \mathrm{~L}$ offshore $\left(3 \mathrm{~L}_{4}\right)$ included all samples (Grand Bank and Avalon Channel) not included in the coastal areas of Div. $3 \mathrm{~L}$ described above. For locations of samples and number of vertebral columns per sample, see Templeman (1981).

\section{Results}

The Labrador-East Newfoundland high-vertebralcount stock complex forms the main biomass of cod from Ungava Bay and Div. $2 \mathrm{G}$ to $3 \mathrm{~K}$ and at the smaller sizes in Div. 3L, but there is a tendency for fish greater than $70 \mathrm{~cm}$ to have lower counts. Gradually from north to south in Div. 3L (inshore), stocks of the Avalon stock complex, with lower vertebral means, provide important contributions especially at the larger sizes. The high-vertebral-count cod usually extended to higher length-ranges northward than southward in these Divisions (Table 1). In Div. $3 M$ there were no obvious trends with length, whereas in Div. 3NO, mean vertebral count increased with increasing length, reached a maximum at an intermediate length group and then declined.

Off Labrador and over the Northeast Newfoundland Shelf (Div. 2GHJ and $3 \mathrm{~K}$ ), offshore vertebral means for the same area and length-range in approximately the same periods (Table 1 and Appendix) were higher in 18 of 20 pairs of offshore and inshore means (13 significantly), and higher inshore but nonsignificantly in 2 pairs.

Differences in vertebral means for the same area and length-range for early and late periods are as follows (numbers of significant differences in parentheses):

\begin{tabular}{lccccc}
\hline & \multicolumn{3}{c}{ Vertebral means } \\
\cline { 2 - 3 } & \multicolumn{2}{c}{$1958-71$} & & $1947-55$ & \\
\cline { 2 - 3 } Area & Lower & Equal & & Lower & Total \\
\hline Div. 2GHJ+3K & $17(9)$ & 0 & 1 & 18 \\
Div. 3L L $_{1}-L_{3}$ (inshore) & $9(5)$ & 2 & $2(2)$ & 13 \\
Div. 3L 4 (offshore) & $4(2)$ & 0 & $1(1)$ & 5 \\
Div. 3M & $3(1)$ & 1 & 0 & 4 \\
Div. 3NO & 2 & 0 & $3(2)$ & 5 \\
\hline
\end{tabular}


TABLE 1. Vertebral means at length ranges of cod from earlier and later periods of 1947-71. (Statistical data in Appendix. NAFO Div. $2 \mathrm{GH}$, off northern Labrador; $2 \mathrm{~J}$, off southern Labrador; $3 \mathrm{~K}$, Northeast Newfoundland Shelf; $3 \mathrm{~L}_{1}$, coastal Div. $3 \mathrm{~L}$, north of St. John's; $3 \mathrm{~L}_{2}$, coastal Div. 3L, St. John's area; $3 \mathrm{~L}_{3}$, coastal $3 \mathrm{~L}$, south of St. John's; 3L4, offshore Div. 3L, northern Grand Bank; 3M, Flemish Cap; 3NO, southern Grand Bank).

\begin{tabular}{|c|c|c|c|c|c|c|c|c|c|}
\hline \multirow{2}{*}{$\begin{array}{l}\text { Fish } \\
\text { length } \\
(\mathrm{cm})\end{array}$} & \multicolumn{9}{|c|}{ Area } \\
\hline & $2 \mathrm{GH}$ & $2 \mathrm{~J}$ & $3 K$ & $3 \mathrm{~L}_{1}$ & $3 \mathrm{~L}_{2}$ & $3 \mathrm{~L}_{3}$ & $3 \mathrm{~L}_{4}$ & $3 \mathrm{M}$ & $3 \mathrm{NO}$ \\
\hline \multicolumn{10}{|c|}{ Early period - Inshore } \\
\hline & $\begin{array}{l}1948-50 \\
\text { Jul-Aug }\end{array}$ & $\begin{array}{c}1948 \\
\text { Jul }\end{array}$ & $\begin{array}{c}1947-54 \\
\text { Jun-Aug }\end{array}$ & $\begin{array}{l}1949-54 \\
\text { Jun-Nov }\end{array}$ & $\begin{array}{l}1947-51 \\
\text { Jun-Nov }\end{array}$ & $\begin{array}{l}1949-54 \\
\text { Sep-Nov }\end{array}$ & & & \\
\hline $11-30$ & - & - & - & - & - & 55.25 & & & \\
\hline $31-50$ & 55.22 & 55.13 & 55.04 & 55.12 & 55.11 & 54.44 & & & \\
\hline $51-70$ & 55.30 & 55.23 & 55.32 & 55.25 & 55.00 & 54.26 & & & \\
\hline $71-90$ & - & 55.17 & 55.16 & 54.92 & 54.51 & 54.13 & & & \\
\hline$>90$ & - & - & - & 54.33 & 54.15 & 54.50 & & & \\
\hline
\end{tabular}

\begin{tabular}{|c|c|c|c|c|c|c|c|c|c|}
\hline \multicolumn{10}{|c|}{ Early period - Offshore } \\
\hline & $\begin{array}{l}1950 \\
\text { Aug }\end{array}$ & $\begin{array}{l}1950-54 \\
\text { Jul-Sep }\end{array}$ & $\begin{array}{l}1950-55 \\
\text { Jun-Sep }\end{array}$ & & & & $\begin{array}{l}1948-55 \\
\text { Apr-Oct }\end{array}$ & $\begin{array}{l}1949-51 \\
\text { Jul-Aug }\end{array}$ & $\begin{array}{l}1947-55 \\
\text { Jan-Oct }\end{array}$ \\
\hline $11-30$ & - & - & - & & & & 55.59 & 54.87 & 53.56 \\
\hline $31-50$ & 55.65 & 55.38 & 55.39 & & & & 54.63 & 54.70 & 53.76 \\
\hline $51-70$ & 55.56 & 55.51 & 55.45 & & & & 54.83 & 54.59 & 53.80 \\
\hline $71-90$ & - & 55.44 & 55.12 & & & & 54.59 & $54.66^{\mathrm{a}}$ & 54.05 \\
\hline$>90$ & - & 54.63 & 54.86 & & & & 54.29 & - & 53.65 \\
\hline \multicolumn{10}{|c|}{ Late period - Inshore } \\
\hline & $1959-64$ & $1959-64$ & $1962-65$ & $1962-70$ & $1963-71$ & $1963-69$ & & & \\
\hline & Jul-Aug & Jul-Sep & Jun-Nov & Feb-Nov & Feb-Dec & May-Nov & & & \\
\hline $11-30$ & - & 55.27 & - & 55.29 & $55.19^{b}$ & 55.25 & & & \\
\hline $31-50$ & 55.12 & 54.84 & 54.58 & 55.02 & 54.83 & 54.76 & & & \\
\hline $51-70$ & 55.25 & 54.98 & 54.77 & 54.74 & 54.61 & 54.54 & & & \\
\hline $71-90$ & 54.79 & 54.44 & 54.54 & 54.41 & 54.25 & 54.00 & & & \\
\hline$>90$ & - & 54.08 & 53.70 & 54.03 & 54.15 & 54.24 & & & \\
\hline \multicolumn{10}{|c|}{ Late period - Offshore } \\
\hline & $1959-60$ & $1958-66$ & $1962-64$ & & & & $1961-70$ & $1961-64$ & 1964-69 \\
\hline & Jul-Sep & Mar-Sep & Apr-Sep & & & & Jan-Oct & Mar-Jul & Apr-Nov \\
\hline $11-30$ & 55.49 & 55.29 & 55.12 & & & & 55.18 & 54.40 & 53.87 \\
\hline $31-50$ & 55.41 & 55.31 & 55.33 & & & & 54.89 & 54.68 & 53.98 \\
\hline $51-70$ & 55.38 & 55.36 & 55.27 & & & & 54.45 & 54.59 & 54.13 \\
\hline $71-90$ & 55.22 & 54.84 & 54.32 & & & & 54.08 & $54.65^{\mathrm{a}}$ & 53.98 \\
\hline$>90$ & - & 55.33 & 54.46 & & & & 54.11 & - & 53.55 \\
\hline
\end{tabular}

${ }^{\mathrm{a}} 71->90 \mathrm{~cm} ;{ }^{\mathrm{b}} 31-40 \mathrm{~cm}$

Thus, for the northern Div. 2GHJ and 3K, comparable vertebral means were lower in the later than in the earlier period. Means of the isolated Flemish Cap stock (Div. 3M) were also lower in the later period. In Div. 3L, means were usually lower in the later than in the earlier period, but not as distinctly so as for the more northern Divisions. In Div. 3NO, in contrast, means of the later period tended to be higher than those of the earlier.

Comparable vertebral means declined from north to south. Comparing means from northern areas (Table 1 and Appendix) for the same length-ranges (for inshore and offshore, early and later periods separately) with those of the more southern adjacent area gave the results below (numbers significantly different in parentheses):

\begin{tabular}{lccc}
\hline & \multicolumn{2}{c}{$\begin{array}{c}\text { Adjacent southern } \\
\text { area mean }\end{array}$} & \\
\cline { 2 - 3 } Area & Lower & Higher & Total \\
\hline Div. 2GHJ+3K & $22(10)$ & 5 & 27 \\
Div. 3K, 3L $-L_{3}$ (inshore) & $17(9)$ & $6(1)$ & 23 \\
Div. 3K, 3L, $3 N$ (offshore) & $18(13)$ & 1 & 19 \\
Total & $57(32)$ & $12(1)$ & 69 \\
\hline
\end{tabular}

\section{Discussion}

Judging by vertebral means and high and low vertebral numbers (Templeman, 1981) the purest part of the Labrador-East Newfoundland stock complex is in Ungava Bay and off northern Labrador where the cod 
are most removed from intermingling with other stocks. The offshore populations of Div. $2 \mathrm{GH}$ to $3 \mathrm{~K}$ are also more typical of the northern stock than the inshore populations, possessing high vertebral numbers except at the greatest length-ranges. Progressively from Div. 2J southward, the largest cod have lower vertebral numbers more typical of southern or Gulf of St. Lawrence stocks or of cod from the coastal areas. The decline in vertebral means from Div. $2 \mathrm{GH}$ to $3 \mathrm{~L}$ indicates that progressively southward there are increasing numbers of low-vertebral-count cod which are evident especially at the greatest lengths.

Possible sources of the low-vertebral-count cod present at the larger sizes toward the north are the occasional migrants from the northern part of the Gulf of St. Lawrence and from the lower-vertebral-count northern coastal cod and Avalon and southern Grand Bank stocks (Templeman and Fleming, 1962; Templeman, 1974, 1979, 1981). The migrants from these areas are likely to be mainly mature fish. The smaller immature cod of the northern Gulf or Grand Bank and related stocks are unlikely to move in numbers to the northern areas. It is evident from Fleming (1960, figure 5) that southern Grand Bank cod mature at larger sizes and attain much greater maximum size than the Labrador cod. The fastest-growing cod, those from the southern Grand Bank, were on the average 30\% longer at age 5 and $75 \%$ longer at age 15 than those from the area of slowest growth, northern Labrador (Templeman, 1965). In the northern Divisions, the numbers of cod at these greater lengths were few compared with those at the smaller lengths and with those at greater lengths in southern areas. Some smaller cod of low vertebral numbers presumably also wander into northern highvertebral-count areas, but, as deduced from vertebral means, are not so evident as at the higher lengthranges where the numbers of the slow-growing highvertebral-count stocks are relatively fewer. It was possible to test whether the movement of large, lowvertebral-count fish into offshore northern areas was of a seasonal nature. In 1958-66 the offshore samples from Div. 2J (Table 1 and Appendix) included 18 samples $(2,288$ cod) from 31 March to 11 June, the spring spawning period, and 7 samples $(764 \mathrm{cod})$ in AugustSeptember, the late summer-early autumn feeding season. Vertebral numbers of these two seasonal groups were as follows:

\begin{tabular}{cccr}
\hline $\begin{array}{c}\text { Length range } \\
\text { of fish } \\
(\mathrm{cm})\end{array}$ & $\begin{array}{c}\text { Mean } \\
\text { vertebral } \\
\text { number }\end{array}$ & $\begin{array}{c}\text { Standard } \\
\text { error }\end{array}$ & $\begin{array}{c}\text { No. of } \\
\text { fish }\end{array}$ \\
\hline \multicolumn{4}{c}{ March to early June } \\
$11-30$ & 55.31 & 0.06 & \\
$31-50$ & 55.28 & 0.02 & 155 \\
$51-70$ & 55.37 & 0.03 & 1,318 \\
$71-110$ & 55.00 & 0.17 & 767 \\
& & & 48
\end{tabular}

\begin{tabular}{cccr} 
(continued). & & \\
\hline $\begin{array}{c}\text { Length range } \\
\text { of fish } \\
(\mathrm{cm})\end{array}$ & $\begin{array}{c}\text { Mean } \\
\text { vertebral } \\
\text { number }\end{array}$ & $\begin{array}{c}\text { Standard } \\
\text { error }\end{array}$ & $\begin{array}{c}\text { No. of } \\
\text { fish }\end{array}$ \\
\hline \multicolumn{4}{c}{ August-September } \\
$11-30$ & 55.23 & 0.11 & 40 \\
$31-50$ & 55.44 & 0.05 & 210 \\
$51-70$ & 55.35 & 0.04 & 483 \\
$71-110$ & 54.74 & 0.18 & 31 \\
\hline
\end{tabular}

The pattern of high vertebral counts in $11-70 \mathrm{~cm}$ fish and lower vertebral counts in $71-110 \mathrm{~cm}$ fish is similar in both sets of monthly periods. The vertebral means at the largest sizes were lower in the later than in the earlier months but the differences at the same lengthranges are not significant. The offshore Div. 3K group in the later period (1962-64), can also be separated into spring (April-May) and early autumn (September) samples (14 samples, 1,909 fish, and 2 samples, 214 fish respectively) with results as follows:

\begin{tabular}{cccr}
\hline $\begin{array}{c}\text { Length range } \\
\text { of fish } \\
(\mathrm{cm})\end{array}$ & $\begin{array}{c}\text { Mean } \\
\text { vertebral } \\
\text { number }\end{array}$ & $\begin{array}{c}\text { Standard } \\
\text { error }\end{array}$ & $\begin{array}{r}\text { No. of } \\
\text { fish }\end{array}$ \\
\hline \multicolumn{4}{c}{ April-May 1962-64 } \\
$11-30$ & 55.10 & 0.05 & 199 \\
$31-50$ & 55.34 & 0.03 & 1,034 \\
$51-70$ & 55.32 & 0.04 & 613 \\
$71-120$ & 54.33 & 0.15 & 63 \\
& & & 30 \\
$11-30$ & September 1962-63 & 67 \\
$31-50$ & 55.30 & 0.18 & 91 \\
$51-70$ & 55.13 & 0.09 & 26 \\
$71-120$ & 54.90 & 0.11 & \\
\hline
\end{tabular}

In both April-May and in September, the $11-50 \mathrm{~cm}$ fish had northern type higher vertebral means in comparison with the lower means of the 71-120 cm fish. The vertebral means of the $51-70 \mathrm{~cm}$ fish were also somewhat low in September but not in April-May. Thus, in both cases examined, season was not an important factor in explaining mean vertebral count variation.

The similar picture of declining vertebral means from small to large fish in northern areas in different periods, $10-15$ years apart, gave no indication that the great decreases in vertebral means with increasing fish length were due to year-class differences in the same stocks. Ten to fifteen years would provide enough time for the high-vertebral-count fish of the earlier periods shown in Table 1 to grow to lengths which actually had low-vertebral-count fish in the later periods.

The Labrador-East Newfoundland stock complex is known to spawn in Div. $2 \mathrm{GHJ}$ and $3 \mathrm{~K}$ and spawning of this stock is doubtful in Div. 3L (Templeman, 1979). 
For Div. 3L, there was a general picture of the smaller fish, i.e. those from settling of fry of the Labrador-East Newfoundland stock complex and their consequent growing up as immatures in the area, possessing the high vertebral numbers characteristic of this northern stock complex. At intermediate sizes there was intermingling with low-vertebral-count cod of the local Avalon stock complex and of the southern Grand Bank to produce lower vertebral numbers. At the greatest lengths, the population was almost entirely of the southern type, with low vertebral numbers, because the northern cod usually do not grow to the greater lengths typical of the southern fish.

Migration studies showed some movement of cod from the southern Grand Bank (Div. 3NO), St. Pierre Bank and vicinity, to Div. $3 \mathrm{~L}$ and vice versa, and return of cod from the spawning areas of the Labrador-East Newfoundland stock complex to their feeding areas in Div. 3L (Thompson, 1943; Templeman and Fleming, 1962; Templeman, 1974, 1979; Lear, 1984).

Southern Grand Bank (Div. 3NO) is occupied mainly by the low-vertebral-count southern Grand Bank stock but with some intrusions from the northward of high-vertebral-count stock (Templeman, 1962, 1974, 1979, 1981; Postolaky, 1962). It is evident that, because of the greater length at sexual maturity and the high growth rate of the southern Grand Bank lowvertebral-count stock and the smaller length at sexual maturity and low growth rate of the high-vertebralcount northern stock complex, these largest fish with the lowest vertebral means were most likely to be southern Grand Bank stock. Similarly the smallest immatures which had the next lowest vertebral means and presumably migrate little compared with larger fish were apparently mostly southern Grand Bank stock. The higher vertebral means of the cod of intermediate length were mainly due to the intrusion of highervertebral-count fish of the northern and Avalon stocks to mix with the southern Grand Bank stock. The extent of these migrations is indicated in Templeman (1974, 1979) and also by the vertebral means of Templeman (1981) and of Postolaky (1962). Much or most of the intrusion is around the northeastern slope of the Grand Bank into the northeastern portion of Div. 3N and from the coast and from northwestern Grand Bank into the northwestern part of Div. 30. The intermediate lengthranges were most affected by the movements from the north and northwest, and the largest were affected very little because the larger immature and the mature slower-growing cod from the north and northwest were mainly of intermediate sizes which, because of their earlier maturity and slower growth, did not usually reach the greater lengths characteristic of the southern Grand Bank stock.

The Flemish Cap cod stock, as reviewed by Templeman (1976) and Lear et al. (1981), was shown by many authors and by many biological differences to be relatively isolated from other cod stocks of the Newfoundland area. The small differences in vertebral means between length-ranges and between periods on Flemish Cap, together with the large degree of isolation of the stock by the deep Flemish Channel, indicate that the small differences in vertebral means on the Cap were due to random differences or to differences between year-classes (Lear et al., 1981).

The trend towards lower vertebral counts in more southern areas is in conformity with the commonly made observation that fish which develop in warmer waters have lower meristic counts. The observation that inshore cod had lower vertebral counts than offshore cod of the same length in Div. $2 \mathrm{GHJ}, 3 \mathrm{~K}$ may be partly related to later spawning in inshore areas, which could also place some inshore eggs and larvae in relatively warmer waters.

There is evidence (Templeman, 1964, and below) that in Div. $2 \mathrm{~J}$ and $3 \mathrm{~K}$, cod spawning closer to the coast have higher percentages of late spawners than those subjected to the main fisheries farther offshore on the continental slopes. Spawning later in the year should produce cod with lower vertebral numbers if upper layer water temperatures are higher. In 9-16 April 1963, in the Hamilton Bank region of Div. $2 \mathrm{~J}$, research vessel samples of 71 mature females from the southeastern and eastern slopes of Hamilton Bank (2J) contained $71 \%$ spent fish, $8 \%$ partly spent and the remainder were ripening to spawn in that year. At the same time in the same general area but in the western part of Hawke Channel, closer to the coast, cod were spawning later. In samples of 28 mature females, the percentages were $28 \%$ spent, $8 \%$ partly spent and $64 \%$ ripening. In early May 1963 in Div. 3K, there was a greater proportion of female cod in research vessel catches spawning later in the deep water of the coastal shelf than on Funk Island Bank where bottom temperatures were higher. In coastal areas $81 \%$ of 155 mature females were spent whereas $91 \%$ of 87 mature females on Funk Island Bank were spent. Bottom water temperatures were $-0.9^{\circ}$ to $2.9^{\circ} \mathrm{C}$ and $2.4^{\circ}$ to $3.3^{\circ} \mathrm{C}$ respectively. In both Div. $2 \mathrm{~J}$ and $3 \mathrm{~K}$, the later spawning was especially evident in the older year-classes and largest sizes.

The observations of Chrzan (1968) for 1967 are indefinite regarding location, but appear to indicate that in the colder water closer to the coast there is later spawning. He says that "from our observations on the maturity of the gonads, it appears that, in Div. $2 \mathrm{~J}$ cod, spawning in the deeper waters was into its final stage in May, whereas in the shallower waters it was considerably retarded". This, along with Canadian research vessel data for 1963, indicates that some delayed spawning occurs in coastal waters, possibly as a result of lower bottom-water temperatures. This could have the result of placing some eggs and larvae in warmer surface 
waters than what prevails during earlier spawning on the offshore banks.

The strong tendency for vertebral counts to be lower in the 1958-71 period than earlier in the inshore northern areas could be partly a result of increased winter-spring catches of the northern stock complex. The offshore catch was twice the inshore catch in Subarea 2 (predominantly in Div. 2J) in 1951-53 (ICNAF, 1952-57). In 1959 the offshore catch from Div. 2J was still twice the inshore catch, whereas in 1960-66 it ranged from 8 to 14 times the inshore catch (Lear et al., 1986). The offshore cod catch in Div. 3K from 1953 to 1955 was 0.3 times the inshore catch (ICNAF, 1952-57) and the yearly offshore catch in 1960-65 averaged 1.7 times the inshore catch (Lear et al., 1986). Most of these offshore catches were taken in winter-spring before the cod migrated inshore from the wintering and spawning areas. In $1969,71 \%$ of the catch of 412,000 tons of cod off Labrador (Subarea 2) was taken in January-March and $92 \%$ before the end of June (Templeman, 1972). The increased fishing in winter-spring on the offshore high-vertebral-count populations in Div. $2 \mathrm{~J}$ and $3 \mathrm{~K}$ left much smaller numbers of these fish to intermingle in summer-autumn with the inshore populations which evidently had more fish with lower vertebral numbers. This would tend to lower the vertebral means of coastal cod in Div. $2 \mathrm{~J}$ and $3 \mathrm{KL}$ in the summer-autumn in the later more than in the earlier period (Table 1).

\section{Conclusions}

1. In Div. $2 \mathrm{GHJ}$ and $3 \mathrm{KL}$, vertebral means of the smaller cod were of the high-vertebral-count northern-type, declining toward the low-vertebralcount southern-type at greater lengths. The highvertebral-type mean extended to higher length-ranges in the north than in the south.

2. In the calculations of vertebral means for the northern part of the eastern Newfoundland area, cod of the larger sizes were relatively scarce, increasing in numbers relative to those at the smaller sizes from north to south.

3. Vertebral means of offshore cod in Div. 2GHJ and $3 \mathrm{~K}$ were typically higher than the inshore means for the same fish length-range, Division and approximately the same periods.

4. Vertebral means in the same area, time period and length-range in Div. 2GHJ and $3 \mathrm{~K}$, and usually for Div. $3 \mathrm{~L}$ and $3 \mathrm{M}$, were higher in the earlier, 1947-55, than in the later, 1958-71, period; the reverse tended to be the case in Div. 3NO.

5. Vertebral means in Div. 2GHJ and 3KLNO were typically lower in the southern than in the adjacent northern Division or combined Divisions at the same length-range, approximate period, and inshore or offshore location. This is explainable by the somewhat later spawning and hence higher upper water temperature at egg development in southern than in northern areas.

6. In Div. $2 \mathrm{~J}$ and $3 \mathrm{~K}$, samples from spring-early June and late summer-early autumn had high vertebral numbers at smaller length-ranges and low vertebral numbers at the largest length-ranges indicating that mixing was a result of straying rather than of seasonal migrations.

7. Stock mixing from drifts of larvae and fry in water currents, later straying of cod of different stocks, often with different growth rates and intermingling of stocks in feeding season account in large part for differences in vertebral numbers observed at different fish length ranges.

8. In Div. $2 \mathrm{~J}$ and $3 \mathrm{~K}$, there was some later spawning in areas closer to the coast than in the truly offshore deepwater areas. The later spawning was relatively greater in the older year-classes and largest sizes. The later spawning could produce lower vertebral numbers in inshore cod compared to offshore cod in the same Division.

9. The greatly increased winter-spring fishery in the early-1960s on the high-vertebral-count populations in offshore Div. $2 \mathrm{~J}$ and $3 \mathrm{~K}$, left much smaller numbers of these fish on their return migration to intermingle with the inshore populations, which evidently had more fish with lower vertebral numbers. This was probably a factor in lowering inshore vertebral numbers in the 1960s.

\section{References}

CHRZAN, F. 1968. Polish research report, 1967. ICNAF Redbook, 1968(II): 75-84.

FLEMING, A. M. 1960. Age, growth and sexual maturity of cod (Gadus morhua L.) in the Newfoundland area, 1947-50. J. Fish. Res. Board Can., 17: 775-809.

ICNAF. 1952-57. Fishery Statistics. ICNAF Stat. Bull., vols. 1-5 for 1951-55.

LEAR, W. H. 1984. Discrimination of the cod stock complex of Atlantic cod (Gadus morhua) off southern Labrador and eastern Newfoundland, as inferred from tagging studies. J. Northw. Atl. Fish. Sci., 5: 143-159.

LEAR, W. H., J. W. BAIRD, J. C. RICE, J. E. CARSCADDEN, G. R. LILLY, and S. A. AKENHEAD. 1986. An examination of factors affecting catch in the inshore cod fishery of Labrador and eastern Newfoundland. Can. Tech. Rep. Fish. Aquat. Sci., 1469: iv $+71 \mathrm{p}$.

LEAR, W. H., and R. WELLS. 1984. Vertebral averages of juvenile cod, Gadus morhua, from coastal waters of eastern Newfoundland and Labrador as indicators of stock origin. J. Northw. Atl. Fish. Sci., 5: 23-31.

LEAR, W. H., R. WELLS, and W. TEMPLEMAN. 1981. Variation in vertebral averages for year-classes of Atlantic cod, Gadus morhua, on Flemish Cap. J. Northw. Atl. Fish. Sci., 2: $57-60$. 
MAY, A. W. A. T. PINHORN, R. WELLS, and A. M. FLEMING. 1965. Cod growth and temperatures in the Newfoundland area. ICNAF Spec. Publ., 6: 545-555.

POSTOLAKY, R. I. 1962. Biology of the Labrador and Newfoundland cod. In: Soviet Fisheries Investigations in the Northwest Atlantic, VNIRO-PINRO, Moscow, p. 338-348 (Transl. for U.S. Dept. Int., Nat. Sci. Found., Washington, D.C. by Israel Prog. Sci. Transl., 1963).

SNEDECOR, G. W., and W. C. COCHRAN. 1980. Statistical methods (7th ed.). The lowa State Univ. Press, Ames, lowa, U.S.A., 507 p.

TEMPLEMAN, W. 1962. Divisions of cod stocks in the Northwest Atlantic. ICNAF Redbook, 1962(III): 79-129.

1964. Canadian research report, 1963. A. Subareas 2 and 3. ICNAF Redbook, 1964(II): 3-21.

1965. Canadian research report, 1964. A. Subareas 2 and 3. ICNAF Redbook, 1965(II): 3-20.

1972. Subarctic marine living resources. Trans. Roy. Soc. Can., Ser. 4, 10: 259-295.

1974. Migrations and intermingling of Atlantic cod
(Gadus morhua) stocks of the Newfoundland area. J. Fish. Res. Board Can., 31: 1073-1092.

1976. Biological and oceanographic background of Flemish Cap as an area for research on the reasons for year-class success and failure in cod and redfish. ICNAF Res. Bull., 12: 91-117.

1979. Migration and intermingling of stocks of Atlantic cod (Gadus morhua), of the Newfoundland and adjacent areas from tagging in 1962-66. ICNAF Res. Bull., 14: 5-50.

1981. Vertebral numbers in Atlantic cod, Gadus morhua, of the Newfoundland and adjacent areas, 1947-71 and their use for delineating cod stocks. J. Northw. Atl. Fish. Sci., 2: 21-45.

TEMPLEMAN, W., and A. M. FLEMING. 1962. Cod tagging in the Newfoundland area during 1947 and 1948. J. Fish. Res. Board Can., 19: 445-487.

THOMPSON, H. 1943. A biological and economic study of cod (Gadus callarias L.) in the Newfoundland area. Nfld. Dept. Nat. Resour. Fish. Bull., 14: 160 p. 


\section{Appendix}

Standard error and sample size (in parenthesis) corresponding to vertebral means of Table 1. (Data calculated to three decimal places and rounded to two.)

\begin{tabular}{|c|c|c|c|c|c|c|c|c|c|c|c|c|c|c|}
\hline \multirow{2}{*}{$\begin{array}{l}\text { Fish } \\
\text { length } \\
(\mathrm{cm})\end{array}$} & \multicolumn{14}{|c|}{ Area } \\
\hline & \multicolumn{2}{|c|}{$2 \mathrm{GH}$} & \multicolumn{2}{|c|}{$2 \mathrm{~J}$} & \multicolumn{2}{|c|}{$3 K$} & \multicolumn{2}{|c|}{$3 L_{1}$} & \multicolumn{2}{|c|}{$3 L_{2}$} & $3 L_{3}$ & $3 \mathrm{~L}_{4}$ & $3 M$ & $3 \mathrm{NO}$ \\
\hline \multicolumn{15}{|c|}{ Early period - Inshore } \\
\hline & \multicolumn{2}{|c|}{$\begin{array}{l}1948-50 \\
\text { Jul-Aug }\end{array}$} & \multicolumn{2}{|c|}{$\begin{array}{c}1948 \\
\text { Jul }\end{array}$} & \multicolumn{2}{|c|}{$\begin{array}{l}1947-54 \\
\text { Jun-Aug }\end{array}$} & \multicolumn{2}{|c|}{$\begin{array}{l}1949-54 \\
\text { Jun-Nov }\end{array}$} & \multicolumn{2}{|c|}{$\begin{array}{l}\text { 1947-51 } \\
\text { Jun-Nov }\end{array}$} & $\begin{array}{l}\text { 1949-54 } \\
\text { Sep-Nov }\end{array}$ & & & \\
\hline $11-30$ & - & & - & & - & & - & & - & & $0.14 \quad(32)$ & & & \\
\hline $31-50$ & 0.05 & (253) & 0.29 & $(16)$ & 0.12 & (96) & 0.07 & (171) & 0.06 & (338) & $0.12(107)$ & & & \\
\hline $51-70$ & 0.04 & (361) & 0.06 & (188) & 0.04 & $(596)$ & 0.04 & (607) & 0.04 & $(850)$ & $0.06(353)$ & & & \\
\hline $71-90$ & - & (4) & 0.54 & (6) & 0.13 & (43) & 0.07 & (209) & 0.07 & (274) & $0.10(127)$ & & & \\
\hline$>90$ & - & & - & & - & & 0.20 & $(27)$ & 0.12 & $(61)$ & $0.32 \quad(16)$ & & & \\
\hline
\end{tabular}

\begin{tabular}{|c|c|c|c|c|c|c|}
\hline \multirow[b]{2}{*}{$11-30$} & \multicolumn{2}{|c|}{$\begin{array}{l}1950 \\
\text { Aug }\end{array}$} & \multicolumn{2}{|c|}{$\begin{array}{c}1950-54 \\
\text { Jul-Sep }\end{array}$} & \multicolumn{2}{|c|}{$\begin{array}{l}1950-55 \\
\text { Jun-Sep }\end{array}$} \\
\hline & - & & - & & - & \\
\hline $31-50$ & 0.08 & (76) & 0.04 & (291) & 0.06 & (239) \\
\hline $51-70$ & 0.07 & (135) & 0.03 & (610) & 0.03 & (827) \\
\hline $71-90$ & - & & 0.14 & (39) & 0.07 & (175) \\
\hline$>90$ & - & & 0.26 & (8) & 0.18 & (22) \\
\hline
\end{tabular}

Early period - Offshore

\begin{tabular}{|c|c|c|c|c|c|c|c|c|c|c|}
\hline \multicolumn{11}{|c|}{ Late period - Inshore } \\
\hline \multirow[b]{2}{*}{$11-30$} & $\begin{array}{l}1959-64 \\
\text { Jul-Aug }\end{array}$ & \multicolumn{2}{|c|}{$\begin{array}{l}\text { 1959-64 } \\
\text { Jul-Sep }\end{array}$} & \multicolumn{2}{|c|}{$\begin{array}{l}1962-65 \\
\text { Jun-Nov }\end{array}$} & \multicolumn{2}{|c|}{$\begin{array}{l}1961-70 \\
\text { Feb-Nov }\end{array}$} & \multicolumn{2}{|c|}{$\begin{array}{c}1963-71 \\
\text { Feb-Dec }\end{array}$} & $\begin{array}{c}1963-69 \\
\text { May-Nov }\end{array}$ \\
\hline & - & 0.05 & (323) & - & & 0.10 & $(104)$ & 0.12 & $(51)^{b}$ & 0.45 \\
\hline $31-50$ & $0.04 \quad(532)$ & 0.04 & (523) & 0.11 & (77) & 0.05 & (482) & 0.06 & (296) & 0.09 (129) \\
\hline $51-70$ & $0.02(1,447)$ & 0.03 & $1,469)$ & 0.08 & (177) & 0.03 & $1,129)$ & 0.04 & (817) & $0.06(369)$ \\
\hline $71-90$ & $0.28 \quad(14)$ & 0.07 & (223) & 0.10 & (151) & 0.04 & (802) & 0.05 & (407) & $0.04(548)$ \\
\hline$>90$ & - & 0.21 & (13) & 0.26 & (20) & 0.07 & (204) & 0.16 & (33) & $0.06(246)$ \\
\hline
\end{tabular}

Late period - Offshore

\begin{tabular}{|c|c|c|c|c|c|c|c|c|}
\hline \multirow[b]{2}{*}{$11-30$} & \multicolumn{2}{|c|}{$\begin{array}{l}\text { 1959-60 } \\
\text { Jul-Sep }\end{array}$} & $\begin{array}{c}1958-66 \\
\text { Mar-Sep }\end{array}$ & $\begin{array}{l}1962-64 \\
\text { Apr-Sep }\end{array}$ & \multirow{2}{*}{$\begin{array}{c}\begin{array}{c}1961-70 \\
\text { Jan-Oct }\end{array} \\
0.07(167)\end{array}$} & $\begin{array}{l}1961-64 \\
\text { Mar-Jul }\end{array}$ & \multicolumn{2}{|c|}{$\begin{array}{c}1964-67 \\
\text { Apr-Nov }\end{array}$} \\
\hline & 0.07 & $(164)$ & $0.03 \quad(195)$ & $0.05 \quad$ (229) & & $0.08 \quad(96)$ & 0.05 & (521) \\
\hline $31-50$ & 0.04 & $(546)$ & $0.02(1,528)$ & $0.03(1,101)$ & $0.04(871)$ & $0.04(274)$ & 0.05 & (516) \\
\hline $51-70$ & 0.04 & (412) & $0.03(1,250)$ & $0.04 \quad(704)$ & $0.04(754)$ & $0.06(184)$ & 0.06 & (304) \\
\hline $71-90$ & 0.22 & (9) & 0.13 & 0.13 & 0.07 (223) & $0.10(49)^{a}$ & 0.07 & (223) \\
\hline$>90$ & - & (1) & 0.33 & 0.45 & 0.09 (105) & - & 0.07 & (145) \\
\hline
\end{tabular}

${ }^{\mathrm{a}} 71->90 \mathrm{~cm} ;{ }^{\mathrm{b}} 31-40 \mathrm{~cm}$. 